\title{
KNOWLEDGE OF ANTI-DISCRIMINATION LEGISLATION AND READINESS TO SEEK ANTI-DISCRIMINATION PROTECTION OF RESPONDENTS EMPLOYED IN THE SYSTEM OF SCIENCE AND HIGHER EDUCATION OF THE REPUBLIC OF CROATIA ${ }^{1}$
}

\author{
Dragana BJELIĆ GAĆEŠA \\ College professor, Polytechnic in Pozega, Croatia \\ E-mail:dbjelic@vup.hr
}

\begin{abstract}
Globally, the population is experiencing two simultaneous processes: growth and aging, which will inevitably affect the number of able-bodied people, and in such circumstances, age discrimination is extremely dangerous. Age discrimination comes to the fore at all stages of the employment process. It begins with attempts to become part of the labour force, and ends with measures designed to encourage earlier exit from the labour market. Age discrimination can imply a number of negative consequences for both young and older people. Negative consequences of age discrimination can be reflected in difficult access to the labour market, employment based on atypical contractual forms, difficulties in advancement and training, differences in working conditions and differences in salaries.

The intention of the paper is to achieve two goals: to point out the seriousness of the consequences of age discrimination in employment and the importance of knowledge of law, and to check the situation in the science and higher education system of the Republic of Croatia when it comes to knowledge of antidiscrimination legislation to seek protection against age discrimination.

In view of the above, the paper is divided into two parts, the general part, the theoretical part and the special part. The theoretical part is focused on definition and analysis of discrimination and age discrimination, statistical indicators of
\end{abstract}

\footnotetext{
${ }^{1}$ This paper is based on a part of the data collected within the implementation of a wider research the basic goal of which was to verify the existence of age discrimination in the system of science and higher education of the Republic of Croatia.
} 
discrimination and age discrimination in the Republic of Croatia, the importance of knowledge of the law and the procedure for protection against discrimination before Croatian courts. Special attention in the theoretical part of the paper is paid to the analysis of the case law of the Court of Justice of the EU regarding age discrimination.

A special part of the paper is focused on the presentation and analysis of data obtained through empirical research. Empirical research verified whether and to what extent respondents, employees in the science and higher education system of the Republic of Croatia were familiar with anti-discrimination legislation, to what extent respondents who experienced age discrimination were willing to react and seek protection of their rights and whether they would be willing to react in the future and seek protection of their rights in court. Employees of two Croatian universities were selected for the research group: Josip Juraj Strossmayer University of Osijek and the University of Rijeka, and data collection was conducted using an online questionnaire posted on the Google Drive platform in the period from May 29 to June 21, 2017. The list of contacts and e-mail addresses of respondents were obtained from the official websites of the constituent universities and their rectors, and a total of 2958 addresses were identified: 1506 at the University of Rijeka and 1452 addresses at the Josip Juraj Strossmayer University in Osijek.

The analyzed results of empirical research showed the following:

1) Only $21.43 \%$ of respondents know that there is a Law on Elimination of Discrimination in the Republic of Croatia and are familiar with its contents

2) There is a statistically significant difference in familiarity with the existence of the Act and familiarity with its contents between employees of different levels of education. Only $10.81 \%$ of respondents with high school know about the Act and are familiar with its content, compared to $21.14 \%$ of respondents with graduate studies and higher education.

3) Only $15.43 \%$ of respondents who had been exposed to age discrimination reacted in some way (addressing the employer, consulting with the union commissioner, addressing the ombudsman, filing a lawsuit)

4) There is a statistically significant difference between teaching, administrative, technical and support staff in responding after exposure to age discrimination, more precisely, administrative 
Knowledge of anti-discrimination legislation and readness to seek...

and technical staff reacted most often in such a situation, in $28.21 \%$ of cases

5) In case of exposure to age discrimination in the future and after exhaustion of all other possibilities, only $13.53 \%$ of respondents would certainly turn to the courts

6) There is a statistically significant difference in terms of readiness to go to the courts between respondents employed on the basis of different types of employment contracts. Respondents who work on the basis of a permanent full-time employment contract would be more likely to go to court in case of exposure to age discrimination compared to respondents employed on the basis of other types of contracts.

7) The most common reasons for not going to court are lack of trust in courts and lengthy proceedings.

Keywords: age discrimination, protection against discrimination, system of science and higher education of the Republic of Croatia

\section{Introduction on discrimination and age discrimination in employment, statistical indicators of the incidence of discrimination and age discrimination in the Republic of Croatia and the importance of knowledge of the law and the procedure for protection against discrimination before Croatian courts}

Since the paper aims to point out the seriousness of the consequences of age discrimination in employment and the importance of knowledge of the law, this chapter focuses on theoretical approaches to these concepts. The paper should also answer the questions of whether employees in the system of science and higher education of the Republic of Croatia know that there is an Law on Elimination of Discrimination in Croatia and whether they are familiar with its content. Furthermore, the paper should answer the question to what extent the respondents who experienced age discrimination were willing to react and seek protection of their rights and to what extent the respondents who, if they experience discrimination in future, would be willing to react and seek protection of their rights in court. The answers to these questions will be presented and analyzed in a separate part of the paper. 


\subsection{Discrimination and age discrimination in employment}

Discrimination is any act that, without reasonable and objective justification, distinguishes between persons or groups of persons based on personal features or characteristics such as race, religion, age, sex, and which adversely reflects on their ability to enjoy all human rights equally and fundamental freedoms in the social, economic, cultural, political, civil or any other area.

De Prins, Vrienlink and Sottiaux hold that "discrimination exists when two different cases are treated in the same way and without reasonable justification" (De Prins, Sottiaux, Vrienlink, 2005, p.3). However, the idea of equality contained in this definition has been frequently criticised for its incompleteness. It left open the question of what the cases that can be considered similar are and in what sense they should be similar in order to be treated in the same way. Westen sought to fill this gap with his definition of equality. According to Westen, equality is "a comparative relationship that exists between two or more different persons or things, and the existence of which can be inferred from joint measurements of relevant standards of comparison and which are found to be indistinguishable from that standard" (Westen, 1982, p.544).

Tryfonidou believes that "discrimination is not just different treatment, but different treatment in equal situations that is not justified" (Tryfonidou, 2009, p.1).

In the broadest sense, discrimination "means deviation from the principle of formal equality (equality of rights); discrimination is a relative term, so there is always the question of similarities or differences in relation to someone or something else" (Rodin, 2003, p. 3-5). The European Court of Human Rights in Abdulazziz, Cabales and Balkandali v. the United Kingdom ${ }^{2}$ in paragraph 72 states that discrimination, within the meaning of Article 14 of the European Conventions for the Protection of Human Rights and Fundamental Freedoms, is different treatment for which "there is no reasonable and objective justification", i.e. if differentiation does not seek to achieve a legitimate aim or if there is no "reasonable relationship of proportionality between the means used and the aim pursued."

Frntić and Maričić hold that the European Court of Human Rights, through its practice, has given rise to a definition of discriminatory treatment that is generally applicable, and according to that definition, "discrimination is any different treatment of essentially the same cases for which there is no reasonable justification. Reasonable justification will not exist if the difference in treatment is not legal, if it does not pursue a legitimate goal and if it is not proportionate to that goal"(Frntić, Maričić, 2006, p.26). The Court of Justice of the EU has a similar approach to the concept of discrimination. Thus, in

\footnotetext{
${ }^{2}$ European Court of Human Rights, Abdulaziz, Cabales, Balkandali v UK, App. No. 9214/80, 9473/81 and 9474/81 (1985)
} 
Knowledge of anti-discrimination legislation and readness to seek...

Cadman $^{3}$ case, paragraph 28, the Court is of the opinion that the principle of non-discrimination prohibits comparable situations from being treated differently, unless such a distinction is objectively justified.

In the field of labour and employment, it is mostly reflected in unequal treatment of older workers, workers with impaired health, women, and trade union members as well as those of different political beliefs and ethnic and national backgrounds. There are different ways in which discrimination in employment can manifest itself, from proposing preferred candidates in vacancies, excluding potential workers during the recruitment process, denying compensations or benefits to certain workers, preventing or hindering advancement, paying different salaries to equally skilled workers in the same job to denying the opportunity to use the employer's resources.

Since the emphasis in the paper is on age discrimination, in the continuation of the paper, attention will be paid to this concept. Speaking of age discrimination, the term that is imposed is "ageism". "Ageism" is a term introduced by Robert Butler in 1969, calling it another form of intolerance, equal to sexism and racism. Later, in 1975, he defined this term as "the process of systematic stereotyping and discrimination against people because they are old" (Butler, 1969 , p. 243). Johnson and Bytheway state that "ageism" is "offensive use of force with respect to age" (Johnson, Bytheway, 1993, p.205).

McGowan states that "ageism" is defined as a negative stereotype and systematic devaluation of people just because of their age (Mc Gowan, 1996, p.71). Iversen, Larsen and Solem believe that the concept of ageism can be summed up in three components of attitudes: cognitive (opinions about the elderly), emotional (feelings about the elderly) and behavioural (actions towards the elderly), (Iversen, Larsen and Solem, 2009, p.10). When opinions and feelings are associated with discriminatory behaviour against the elderly, it is age discrimination.

In contrast to ageism, age discrimination is when one particular age group is treated differently from another age group based on chronological age (Sargeant, 2011, p.1). In this regard, age discrimination can be considered a practical manifestation of ageism which is mostly reflected negatively in relation to the elderly. Age discrimination can be defined as different and discriminatory treatment based on age, a range of prejudices or negative assumptions and stereotypes about older people (Pearson, 1996, p.12). Furthermore, it should be noted that age discrimination in employment consists in using the age of the individual as a decisive factor in making decisions related to employment, dismissal, promotion, but also mandatory retirement. There is no doubt that in practice "ageism" and age discrimination will be closely intertwined, for example, in the way that employers' negative prejudices

\footnotetext{
${ }^{3}$ Court of Justice of the EU, Case C-17/05 B.F.Cadman v Health and Safety Executive (2006)
} 
stemming from their fear of their own aging and inability affect personnel policy-making towards older workers (Macnicol, 2006, p.6).

A significant number of authors focused their research on age discrimination in employment. In 2004, List found the existence of age discrimination by researching the product market. The results showed that white men aged 60 and over face discrimination, regardless of whether they participate in the market as buyers or sellers. The results of a survey conducted by Lahey in 2005 showed that employers treat older workers worse than younger ones, that the demand for labour of older workers is lower than younger ones, and that younger workers will receive job offers, as a rule, in shorter time compared to older workers. The research was conducted in such a way that job applications of potential employees of different ages were sent to the employer, and then the time in which employers responded to such requests was measured, the time in which potential candidates were invited for an interview. The results showed that younger workers were more likely to be invited for an interview compared to older workers (a worker aged 50 and over). Furthermore, the time required for an older worker and a younger worker to find a job was compared and it was found (assuming that both older and younger workers apply for all available advertisements each week) that a younger worker would receive a job offer within a week, while the older worker would have to wait three weeks for it (Lahey, 2005, p. 3-4). Van den Heuvel and van Santvoort conducted a survey on the experience of age discrimination in 2011, focusing on direct age discrimination against the elderly (aged 65 and over) in 28 EU countries. The results showed that women aged 62 and over experienced age discrimination to a greater extent than men. Being too young can have negative consequences as well as being too old, according to a 1999 study by Ed Snape and Tom Redman, who believed that the issue of age discrimination must be of strategic importance to both employers and state governments, if negative attitudes and behaviours related to the experience of discrimination are taken into account. The research was conducted on a representative sample (with regard to age, gender and full-time work). The average age of the sample was 44.3 years, noting that the minimum age of the respondents was 17 years, and the maximum was 64 years (Snape, Redman, 2003, p.81, 88).

\subsection{Statistical indicators of the incidence of discrimination and age discrimination in the Republic of Croatia}

Statistical indicators of the incidence of discrimination in the Republic of Croatia indicate that in 2019 the Ombudsman received 2,446 complaints, 270 of which concerned discrimination (Report of the Ombudsman, 2020, p.3). Out of 270 complaints concerning discrimination, 98 complaints concerned discrimination in the field of labour and employment (Report of the Ombudsman, 2020, p.7). Age as a basis for prohibited discrimination is stated in 14 complaints. The number of complaints addressed to the Ombudsman is 
Knowledge of anti-discrimination legislation and readness to seek...

growing and in 2020, it amounted to 2,919 complaints, which is an increase of $16 \%$ compared to the previous year (Report of the Ombudsman, 2021, p. 4).

Out of a total of 2,919 complaints received, 266 concerned discrimination (Report of the Ombudsman, 2021, p. 4), and 76 of them concerned discrimination in the field of labour and employment (Report of the Ombudsman, 2021, p. 9). Age as the basis of prohibited discrimination is stated in 9 complaints (Report of the Ombudsman, 2021, p.9). Despite the above data, an exceptional problem in Croatian society, and consequently in the fight against discrimination, is the still insufficient reporting on discriminatory treatment.

The results of this research will show whether and to what extent the employees in the science and higher education system of the Republic of Croatia are ready to report discriminatory treatment based on the age to which they were exposed or to which they could be exposed in the future.

\subsection{The importance of knowing the rights and the procedure for exercising protection against discrimination before Croatian courts}

Discrimination as an unwanted social phenomenon has a negative effect on the realization of employment rights. However, in addition to discrimination, a potential threat to employment rights is lack of information, ignorance of rights, ignorance of opportunities and ways of protection. We will agree that one of the important factors in the protection and exercise of rights is awareness of or familiarity with law (Miličić, 2008, p.94). It should be noted that the awareness of law tends to reconcile two paradoxes in law, the first according to which "law is created with advance and highly probable awareness of its disrespect" and the second according to which "the creator of law links the establishment and survival of law with the idea of knowing the law" (Miličić, 2008, p.95). This could be summarized in the two Latin maxims "Ignoratia iuris cuiqe nocet"4 and "Ignoratia legis neminem excusat."

Regarding the above, the situation in the science and higher education system of the Republic of Croatia in the context of knowledge of the Croatian Law on Elimination of Discrimination, all in the light of whether respondents know that there is a Law on Elimination of Discrimination in the Republic of Croatia and whether they are familiar with its contents will be presented and analyzed in a special part of the paper.

The provisions of the Law on Elimination of Discrimination governing court proceedings are extremely important in the context of preventing discrimination. In this regard, it should be pointed out that Art.16 of the Law provides for the possibility of achieving protection against discrimination in two ways. First, a person who considers that his/her right has been violated due

\footnotetext{
${ }^{4}$ Ignorance of the law harms everyone

${ }^{5}$ Ignorance of the law is no excuse for anyone
} 
to discrimination, can exercise the protection of the violated right in the proceedings in which this right is decided as the main one. In such a proceeding, the existence of discrimination would be decided as a prejudicial issue (Pavlović, 2009, p.166), whereby success in the dispute on the main issue would depend on a positive solution to the prejudicial issue. For example, if a victim of discrimination seeks damages for discrimination, the claim for damages is the main issue, and the question of the existence of discrimination for which the damage arose is a prejudicial issue. In that case, only a positive solution to the prejudicial issue, therefore, finding that discrimination existed, can result in a positive solution to the main issue, i.e. the right to compensation for discrimination. This would be an incidental protection against discrimination (Uzelac, 2010, p. 95).

Another way of achieving protection against discrimination is the possibility of seeking protection in a special procedure in which the existence of discrimination will be decided as the main issue. This is a special individual discrimination lawsuit (Uzelac, 2010, p.95). It should be emphasized here that special procedures for protection against discrimination in the field of labour and employment will be considered employment disputes pursuant to the provisions of the aforementioned Law.

If a person who considers that he/she is a victim of discrimination decides to seek protection in a special procedure, he/she has three special lawsuits at his/her disposal: a lawsuit to establish discrimination (declaratory lawsuit), a lawsuit to prohibit or eliminate discrimination (condemnatory lawsuit) and a lawsuit for damages (Triva, Dika, 2004, p. 393).

One of the novelties introduced by the Law on Elimination of Discrimination in the field of protection against discrimination concerns the institution of a class action. A class action can generally be defined as "a lawsuit by which an association, a non-profit legal entity established to achieve certain socially permissible goals, initiates proceedings to provide (as a rule) abstract protection of certain rights and interests of its members i.e. members of a particular social group; it is one of the instruments of judicial protection of the so-called group, class, collective and diffuse rights and interests " (Triva, Dika, 2004, p. 824). It should be noted that the institution of a class action is not a novelty in Croatian law at all, since until the enactment of the mentioned Law, it was used in the context of protection of consumer rights and interests (Uzelac, 2010, p.103). With the adoption of the Law on Elimination of Discrimination, its application was extended to discrimination lawsuits, which opened the way to the realization of collective protection of rights, the so-called abstract judicial protection.

The class action for protection against discrimination has certain peculiarities in relation to the three previously mentioned lawsuits. Pursuant to the provisions of Article 24 of the Law on Elimination of Discrimination, the lawsuit is not filed by individuals to protect their own interests, but by associations, bodies, institutions or other organizations that have a legitimate 
Knowledge of anti-discrimination legislation and readness to seek...

interest in protecting the collective interests of a particular group or are engaged in protecting the right to equal treatment (Bjelić, 2018, p.87.). These individuals may file a class action lawsuit against a person who has violated the right to equal treatment if they make it probable that such treatment violated the right to equal treatment of a large number of persons who belong to a group whose rights are being protected. ${ }^{6}$ This standard of probability is another feature that is characteristic of a judicial protection against discrimination. Taking into account the fact that it is very difficult to prove with certainty that there is discrimination in a specific case, the Law on Elimination of Discrimination deviated from the standard rules of procedural law on the burden of proof and in Article 20 prescribed that the plaintiff must make it probable that discrimination has occurred, and when he/she does so, the burden of proving that there was no discrimination shifts to the defendant, the so-called rule on shifting the burden of proof (Uzelac, 2010, p.101). Otherwise, in standard civil proceedings, the burden of proof lies with the plaintiff, who is obliged to prove with a degree of certainty the fact on which his/her claim is based. The county court has the subject matter jurisdiction for the class action in the first instance. In this regard, the Law on Elimination of Discrimination in Article 24 paragraph 3 stipulates that the first-instance association lawsuit is decided by the county court with general territorial jurisdiction over the defendant, or the county court of the place where the act of discrimination was committed or the Zagreb County Court.

\section{Age discrimination in the case law of the Court of Justice of the EU}

In this chapter, attention will be paid to the analysis of individual decisions of the Court of Justice of the EU regarding age discrimination. Taking into account the fact that there is a significant number of such decisions, the paper will briefly analyze court decisions in, in the author's opinion, the most important cases, in order to present its approach to age as one of the grounds for prohibited discrimination. In the context of age discrimination, an extremely important case of the Court of Justice of the EU is undoubtedly C- 144/04 Werner Mangold v Rudiger Helm. ${ }^{7}$

Deciding in the Mangold case, the Court agreed that the less favourable treatment that for older workers stemmed from the German law in 2002 represented different treatment on grounds of age. Furthermore, it found that such a difference in treatment could not be objectively justified, thus rejecting the German Government's argument that special discriminatory measures were justified in order to ensure greater employability of older workers. In the Court's view, a reduction in employment protection for workers of a certain age cannot be objectively justified by reference to vague arguments such as increasing the

\footnotetext{
${ }^{6}$ The peculiarity of this lawsuit is reflected in the fact that it could not be a claim for damages, but also in terms of the actual jurisdiction of the courts to decide on it.

${ }^{7}$ Court of Justice of the EU, Case C-144/04 Werner Mangold v Rudiger Helm (2005)
} 
employability of one age group (O'Cinneide, 2010, p.12). With this decision, the Court surprised many. In this case the Court, despite those who insisted on the special nature of age as the basis of prohibited discrimination ${ }^{8}$ as well as the need to apply the objective justification test in a less rigorous way in the case of age discrimination, indicated that the principle of non-discrimination on grounds of age must be considered a general principle of Community law (Court of Justice of the EU, Case C-144/04 Werner Mangold v Rudiger Helm, 2005, para. 75).

The Court's decision in the Mangold case has been the subject of serious academic criticism on various grounds. Some of the criticisms focused on the observed deviations from the rules on limiting the horizontal direct effect of directives as well as the fact that it included age in the general principle of equal treatment, while national rights across the European Union faced a lack of protection against age discrimination (O'Cinneide, 2010, p.14).

In the time after the decision in the Mangold case, the direction of the case law of the Court of Justice of the EU on age discrimination has become uncertain, and which is supported by the decision of the Court in the Lindorfer case. ${ }^{9}$ In the said case, independent lawyer Jacobs, in his initial opinion written before the judgment in Mangold case has been rendered, suggested that age could not be treated as equivalent to gender or other grounds of prohibited discrimination. What is particularly important is the decision of the Grand Chamber of the Court in this case, who resolved the case without invoking age discrimination as well as without invoking the general principle of equal treatment. This absence of any discussion on the general principle of equal treatment and discrimination on grounds of age cast doubt on the Court's approach in the Mangold case.

In Palacios de la Villa case ${ }^{10}$ the Court reaffirmed the rigorous nature of the prohibition of age discrimination laid down in Directive 2000/78, but on the other hand, considered that the complexity of the issue of retirement age justified giving Member States a relatively wide discretion when it came to employment policy (Court of Justice of the EU, Case C- 411/05 Felix Palacios de la Villa v Cortefiel Servicios, 2007, paragraph 72). In this case, the Court adopted an alternative approach by reaffirming effectively the general approach to provisions on age discrimination as it did in the Mangold case, but with one important difference from the Mangold case. In the Palacios de la Villa case, the Court left open the question of the relationship between the prohibition of age discrimination and the principle of equal treatment and it did not even consider their connection respectively.

\footnotetext{
8 This refers in particular to the suggestions of independent lawyers who considered that age should not be treated in the same way as gender and other grounds for prohibited discrimination. (auth. com.).

${ }^{9}$ Court of Justice of the EU, Case C-227/04 Lindorfer v Council of the European Union (2007)

${ }^{10}$ Court of Justice of the EU, Case C- 411/05 Felix Palacios de la Villa v Cortefiel Servicios (2007)
} 
Knowledge of anti-discrimination legislation and readness to seek...

Controversy over the verdict in the Mangold case has also drawn attention in the Bartsch v Bosch and Siemens case. ${ }^{11}$ In its judgment, the Court concluded that the alleged discriminatory treatment in the present case had nothing to do with Community law, unlike in the Mangold case, where the rules were linked to the implementation of Directive 2000/78. In this decision, the Court emphasized, on the one hand, its intention to maintain the full scope of the decision in the Mangold, while clarifying that its influence was limited to issues within the general scope of Community law (O'Cinneide, 2010, p.28).

The Court in the Age Concern England case applied an analysis similar to that in the Palacios de la Villa case. ${ }^{12}$

The decisions of the Court of Justice of the EU in the Palacios de la Villa and Age Concern England established a general template in the context of the Court's interpretation of the provisions on age discrimination contained in Directive 2000/78. Such a proposal does not rely on the link between age discrimination and the general principle of equal treatment, but is based on the interpretation of the wording of the directives itself. This template has been applied in a number of cases such as C-88/08 Hütter ${ }^{13}, \mathrm{C}-341 / 08$ Peterson $^{14}$, C-229/08 Wolf ${ }^{15}$, C-20/13 Daniel Unland ${ }^{16}$, C-159/15 Franz Lesar ${ }^{17}$, C-258/15 Gorka Salaberria Sorondo ${ }^{18}$.

The Kücükdeveci case $^{19}$ is also extremely important in which the Court confirms its decision rendered in Mangold case, using at the same time the opportunity to clarify its impact and consequences, as well as the relationship between the provisions contained in Directive 2000/78, the general principle of equal treatment and national law (O'Cinneide, 2010, p. 26).

The provisions of the Directive $2000 / 78$ on age discrimination were also discussed in the Bulicke case ${ }^{20}$ concerning the time limits within which age

${ }^{11}$ Court of Justice of the EU, Case C-427/06 Birgit Bartsch v Bosch und Siemens Hausgerate Altersfursorge Gmb (2008)

${ }^{12}$ Court of Justice of the EU, Case C-388/07 Age Concern England v Secretary of State for Business, Enterprise and Regulatory Reform (2009)

${ }^{13}$ Court of Justice of the EU, Case C-88/08 Hütter v Technische Univerzitat Graz (2009)

14 Court of Justice of the EU, Case C-341/08 Dr Dominica Peterson v Berufungsausschuss fur Zahnaerte fur den Bezirk Westfalen-Lippe (2010)

${ }^{15}$ Court of Justice of the EU, Case C-229/08 Colin Wolf v Stadt Frankfurt am Main (2010)

${ }^{16}$ Court of Justice of the EU, Case C-20/13 Daniel Unland v Land Berlin (2015)

${ }^{17}$ Court of Justice of the EU, Case C-159/15 Franz Lesar v Beim Vorstand der Telekom Austra AG (2016)

${ }^{18}$ Court of Justice of the EU, Case C-258/15 Gorka Salaberria Sorondo v Academia Vasca de Policia y Emergencias (2016)

${ }^{19}$ Court of Justice of the EU, Case C-555/07 Seda Kücükdeveci v Swedex GmbH (2010)

${ }^{20}$ Court of Justice of the EU, Case C-246/09 Susanne Bulicke v Deutsche Büro Service GmbH (2010) 
discrimination requirements must be set, as in the Rosenbladt case ${ }^{21}$ in which the Court of Justice of the EU was asked whether national laws, which allow collective agreements to set the age of 65 as the mandatory retirement age, are compatible with Article 6, para 1 of the Directive.

Looking at the previously analyzed decisions of the Court of Justice of the EU, it can be concluded that some of them rely on the link between age discrimination and the general principle of equal treatment, while the others are based on the interpretation of the text of the Directive.

In the context of the decisions that rely on the link between age discrimination and the general principle of equal treatment, it can be concluded that the Court of Justice of the EU has established the prohibition of age discrimination as a general principle of equal treatment that is a fundamental value of the EU legal order.

Furthermore, in its decisions the Court has found that national courts must give effect to the general principle of equal treatment without regard to national laws that are contrary to it and even where this results in a horizontal effect of directives between private individuals.

Likewise, the Court of Justice of the EU has recognized the peculiar nature of age discrimination, which has given Member States a relatively wide discretion that they can use in the event of different treatment based on age.

The review of the Court's decisions shows the Court's awareness of the need to treat age in a way similar to any other ground of prohibited discrimination. Regarding the decisions dealing with the interpretation of the text of the Directives, conclusions on the manner in which the Court conducts the proportionality test can be made. In this regard, it should be noted that the Court determines the existence of a legitimate aim and, if it finds that it exists, assesses the appropriateness and necessity of measures to achieve it. The existence of a legitimate aim was mainly related to employment and labour market policy, promoting the integration of young people in the labour market, protecting public health, ensuring greater flexibility in the labour market and ensuring the operational capacity and proper functioning of certain services (fire fighting and police) and the Court followed its earlier decisions as well as the reasons it designated in as legitimate and proportionate previous similar cases.

\section{Methodology}

Data collection was conducted using an online questionnaire posted on the Google Drive platform in the period from May 29 to June 21, 2017. The

21 Court of Justice of the EU, Case C-45/09 Gisela Rosenbladt v Oellerking Gebaeudereinigungsgesselschaft (2010) 
Knowledge of anti-discrimination legislation and readness to seek...

questionnaire consisted of 22 questions, three of which were open-ended (no pre-offered answers) and the rest closed-ended. Attitudes about discrimination were measured using Likert-type questions with five levels of agreement (from "completely agree" to "strongly disagree"). Such a questionnaire was sent by e-mail with a request to participate in the research to all employees of the aforementioned universities. It is important to point out that in addition to the invitation to participate in the research, the respondents are also guaranteed the anonymity of their answers. Anonymity, which in this case was extremely important due to the sensitivity of the topic, was complete taking into account the fact that the identity of the survey participants could in no way be revealed from their answers, and the Google Drive platform does not allow the person who posted the questionnaire to identify the person who filled it out (using IP addresses or in any other way), with which fact the respondents were familiar. A total of 96 messages remained undelivered in this survey, mainly because the addresses were non-existent (due to out-of-date lists on the university website) or due to the e-mail boxes being full. A total of 532 completed questionnaires were received, which makes a response rate of $18.59 \%$, which can be considered acceptable for this type of research. It should be noted that in relation to variables of nominal type, i.e. when there was no more-or-less ratio between the categories, the chi-square test was used and Cramer's V as a correlation coefficient if the chi-square indicator was statistically significant. Furthermore, within the subject research, in addition to the frequency of answers to individual questions, the demographic differences in the answers to the questions were investigated with regard to age, gender, level of education, type of job, year of service and type of employment contract.

\section{Results of empirical research}

In order to check whether the respondents, the employees of the two Croatian universities, are familiar and to what extent with the Croatian anti-discrimination legislation, they were asked the question:

"Do you know that there is the Law on Elimination of Discrimination in the Republic of Croatia?" and they were offered the following answers:

a) Yes, and I am familiar with its contents

b) Yes, but I am not familiar with its contents

c) No, and I am not familiar with its contents.

The results of the survey showed that only $21.43 \%$ of them answered that they knew that there was an Law on Elimination of Discrimination in the Republic of Croatia and that they were familiar with its contents. 
Graph 1 Familiarity with the Law on Elimination of Discrimination

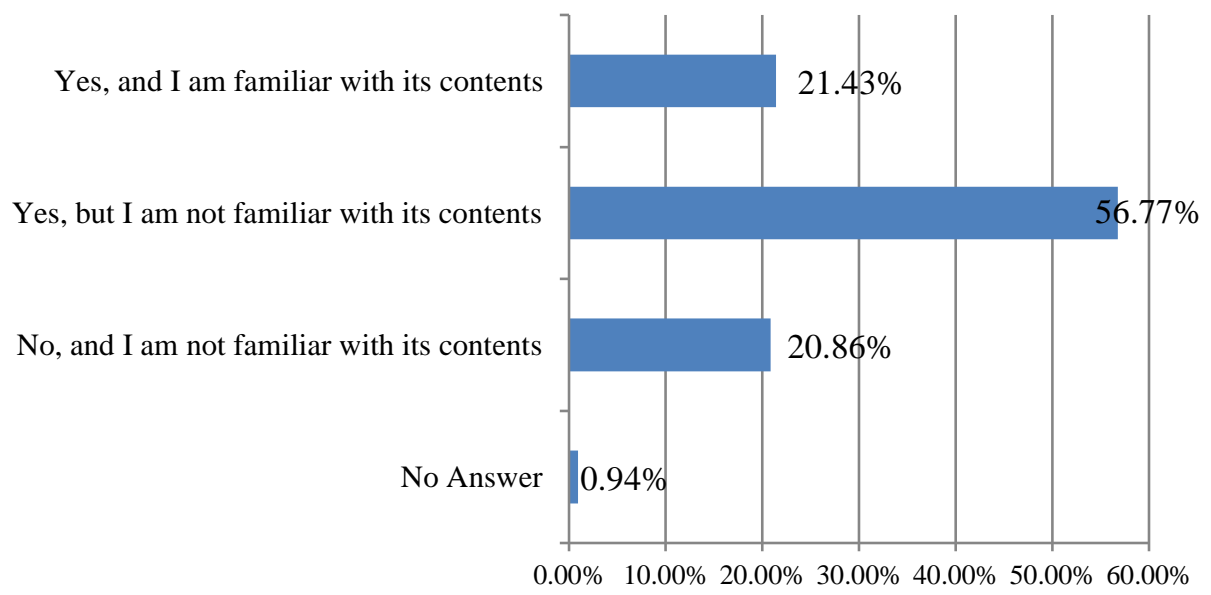

Source: Author's processing according to the results of empirical research

When it comes to demographic differences in terms of being familiar with the Law on Elimination of Discrimination, only the difference in terms of level of education was found (Table 3), and other demographic differences are not statistically significant. Thus, there is no statistically significant difference regarding gender (Table 1). It is evident that the percentage of men and women who chose certain options is similar. For example, $22.40 \%$ of men and $21.26 \%$ of women know about the existence of this Law and are familiar with its contents. 
Knowledge of anti-discrimination legislation and readness to seek...

Table 1 - Familiarity with the Law on Elimination of Discrimination - gender differences

\begin{tabular}{|l|l|l|l|l|}
\hline & $\begin{array}{l}\text { Yes, and I am } \\
\text { familiar with its } \\
\text { contents }\end{array}$ & $\begin{array}{l}\text { Yes, but I am not } \\
\text { familiar with its } \\
\text { contents }\end{array}$ & $\begin{array}{l}\text { No, and I am not } \\
\text { familiar with its } \\
\text { contents }\end{array}$ \\
\hline Male & 43 & 109 & 40 & 192 \\
\hline Female & $22,40 \%$ & $56,77 \%$ & $20,83 \%$ & $100,00 \%$ \\
\hline Total & 71 & 193 & 70 & 334 \\
\hline & $21,26 \%$ & $57,78 \%$ & $20,96 \%$ & $100,00 \%$ \\
\hline
\end{tabular}

$\chi^{2}=0,10 ; \mathrm{p}=0,95$

Source: Author's processing according to the results of empirical research

Likewise, there is no statistically significant difference between teaching, administrative, technical and support staff in terms of being familiar with the Law on Elimination of Discrimination (Table 2). It can be seen that, for example, the share of teaching staff that do not know about the Law and are not familiar with its content is $21.23 \%$, for administrative and technical staff this share is $19.82 \%$, and for support staff $21.74 \%$.

Table 2 - Familiarity with the Law on Elimination of Discrimination differences between teaching, administrative, technical and support staff in equal opportunities for promotion with regard to age

\begin{tabular}{|c|c|c|c|c|}
\hline & $\begin{array}{l}\text { Yes, and I am } \\
\text { familiar with its } \\
\text { contents }\end{array}$ & $\begin{array}{l}\text { Yes, but I am not } \\
\text { familiar with its } \\
\text { contents }\end{array}$ & $\begin{array}{l}\text { No, and I am } \\
\text { not familiar } \\
\text { with } \quad \text { its } \\
\text { contents }\end{array}$ & Total \\
\hline Teaching staff & $\begin{array}{l}78 \\
19,95 \%\end{array}$ & $\begin{array}{l}230 \\
58,82 \%\end{array}$ & $\begin{array}{l}83 \\
21,23 \%\end{array}$ & $\begin{array}{l}391 \\
100,00 \%\end{array}$ \\
\hline $\begin{array}{l}\text { Administrative and } \\
\text { technical staff }\end{array}$ & $\begin{array}{l}32 \\
28,83 \%\end{array}$ & $\begin{array}{l}57 \\
51,35 \%\end{array}$ & $\begin{array}{l}22 \\
19,82 \%\end{array}$ & $\begin{array}{l}111 \\
100,00 \%\end{array}$ \\
\hline Support staff & $\begin{array}{l}4 \\
17,39 \%\end{array}$ & $\begin{array}{l}14 \\
60,87 \%\end{array}$ & $\begin{array}{l}5 \\
21,74 \%\end{array}$ & $\begin{array}{l}23 \\
100,00 \%\end{array}$ \\
\hline Total & $\begin{array}{l}114 \\
21,71 \%\end{array}$ & $\begin{array}{l}301 \\
57,33 \%\end{array}$ & $\begin{array}{l}110 \\
20,95 \%\end{array}$ & $\begin{array}{l}525 \\
100,00 \%\end{array}$ \\
\hline
\end{tabular}


$\chi^{2}=4,33 ; p=0,36$

Source: Author's processing according to the results of empirical research

As mentioned earlier, there is a statistically significant difference in knowing that there is the Law on Elimination of Discrimination and being familiar with its contents between employees of different levels of education (Table 3). Employees with secondary school are the least familiar with the Law. In only $10.81 \%$ of cases they stated that they knew about the Law and that they were familiar with its contents. For persons with graduate studies and higher levels of education, this share is $21.14 \%$, and for persons with completed undergraduate studies (only 17 of them in the sample who answered this question) as much as $58.82 \%$.

Table 3 - Familiarity with the Law on Elimination of Discrimination differences with regard to the level of education

\begin{tabular}{|l|l|l|l|l|}
\hline & $\begin{array}{l}\text { Yes, and I am } \\
\text { familiar with } \\
\text { its contents }\end{array}$ & $\begin{array}{l}\text { Yes, but I am } \\
\text { not familiar } \\
\text { with } \\
\text { contents }\end{array}$ & $\begin{array}{l}\text { No, and I am } \\
\text { its } \\
\text { not } \\
\text { with } \\
\text { contents }\end{array}$ \\
\hline $\begin{array}{l}\text { Graduate study and } \\
\text { higher }\end{array}$ & 100 & 275 & 98 & 473 \\
\hline $\begin{array}{l}\text { Undergraduate } \\
\text { study }\end{array}$ & $21,14 \%$ & $58,14 \%$ & $20,72 \%$ & $100,00 \%$ \\
\hline Secondary school & 10 & 5 & 2 & 17 \\
\hline Total & $58,82 \%$ & $29,41 \%$ & $11,76 \%$ & $100,00 \%$ \\
\hline & $10,81 \%$ & 22 & 11 & 37 \\
\hline
\end{tabular}

$\chi^{2}=17,37 ; p=0,00 ;$ Cramer's V $=0,13$

Source: Author's processing according to the results of empirical research

When it comes to the type of employment contract and being familiar with the Law on Elimination of Discrimination, no statistically significant differences were found (Table 4). 
Knowledge of anti-discrimination legislation and readness to seek...

Table 4 - Familiarity with the Law on Elimination of Discrimination - by type of employment contract

\begin{tabular}{|l|l|l|l|l|}
\hline & $\begin{array}{l}\text { Yes, and I am } \\
\text { familiar with } \\
\text { its contents }\end{array}$ & $\begin{array}{l}\text { Yes, but I am } \\
\text { not familiar } \\
\text { with } \\
\text { contents }\end{array}$ & $\begin{array}{l}\text { No, and I am } \\
\text { not familiar } \\
\text { with } \\
\text { contents }\end{array}$ & Total \\
\hline $\begin{array}{l}\text { Permanent } \\
\text { full-time }\end{array}$ & 85 & 193 & 68 & 346 \\
\hline $\begin{array}{l}\text { Fixed-term } \\
\text { full-time }\end{array}$ & $24,57 \%$ & $55,78 \%$ & $19,65 \%$ & $100,00 \%$ \\
\hline Part-time & $14,46 \%$ & 103 & 39 & 166 \\
\hline Total & $28,57 \%$ & $62,05 \%$ & $23,49 \%$ & $100,00 \%$ \\
\hline
\end{tabular}

$\chi^{2}=8,14 ; p=0,09$

Source: Author's processing according to the results of empirical research

No statistically significant difference was found between universities either, although it is close to the limit of statistical significance $(p=0.06)$.

Table 5 - Familiarity with the Law on Elimination of Discrimination differences between the University of Osijek and the University of Rijeka

\begin{tabular}{|l|l|l|l|l|}
\hline \multicolumn{2}{|c|}{$\begin{array}{l}\text { Yes, and I am } \\
\text { familiar with its } \\
\text { contents }\end{array}$} & $\begin{array}{l}\text { Yes, but I am not } \\
\text { familiar with its } \\
\text { contents }\end{array}$ & $\begin{array}{l}\text { No, and I am } \\
\text { not } \\
\text { with } \\
\text { contents }\end{array}$ & Tamiliar \\
\hline $\begin{array}{l}\text { University of } \\
\text { Osijek }\end{array}$ & 72 & 164 & 48 & 284 \\
\hline $\begin{array}{l}\text { University of } \\
\text { Rijeka }\end{array}$ & 42 & $57,75 \%$ & $16,90 \%$ & $100,00 \%$ \\
\hline Total & $17,28 \%$ & 138 & 63 & 243 \\
\hline
\end{tabular}

$\chi^{2}=9,02 ; p=0,06$

Source: Author's processing according to the results of empirical research 
In order to check the extent to which respondents who experienced age discrimination were willing to react and ask for protection of their rights, the following question was asked: "In case you have been exposed to age discrimination, have you reacted in any way (addressing the employer, consulting with the union commissioner, addressing the ombudsman, filing a lawsuit)?" and the following answers offered:

a) Yes

b) No.

c) I have not been exposed to age discrimination.

The chart below shows the responses of only those participants in the research who were exposed to such discrimination, and they show that only $15.43 \%$ of respondents responded to such a situation.

Graph 2 Response after exposure to age discrimination:

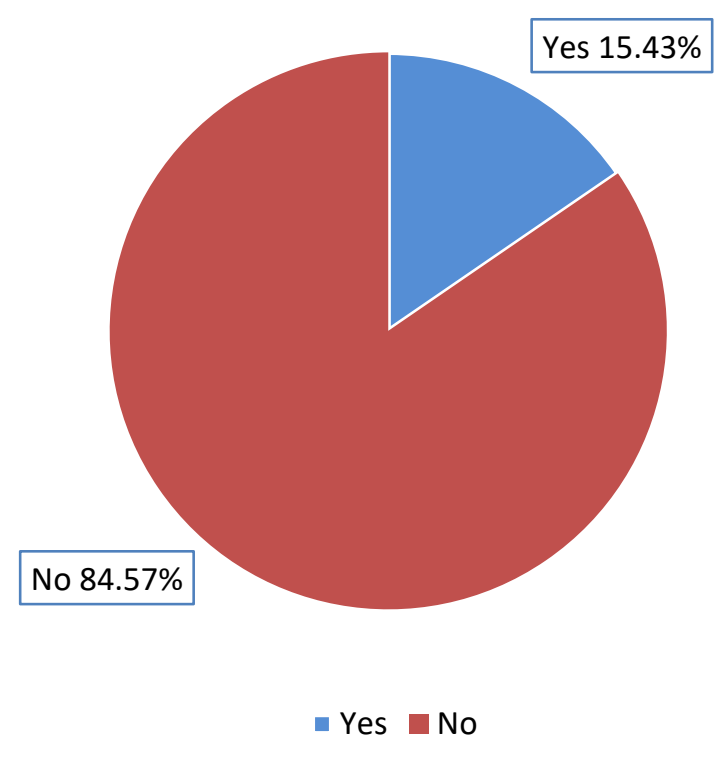

Source: Author's processing according to the results of empirical research

In this respect, a statistically significant difference was found only between teaching, administrative, technical and support staff. Administrative and technical staff responded most often in such a situation - in $28.21 \%$ of situations, and this share is somewhat lower in the other two groups (Table 6). 
Table 6 - Differences between teaching, administrative and technical and support staff in responding to age discrimination

\begin{tabular}{|l|l|l|l|}
\hline \multicolumn{2}{|l|}{ Yes } & 110 & 125 \\
\hline Teaching staff & 15 & $88,00 \%$ & $100,00 \%$ \\
\hline $\begin{array}{l}\text { Administrative and } \\
\text { technical staff }\end{array}$ & $12,00 \%$ & 28 & 39 \\
\hline Support staff & $28,21 \%$ & $71,79 \%$ & $100,00 \%$ \\
\hline Total & $9,09 \%$ & 10 & 11 \\
\hline & 27 & $90,91 \%$ & $100,00 \%$ \\
\hline
\end{tabular}

$\chi^{2}=6,34 ; \mathrm{p}=0,04 ;$ Cramer's V=0,19

Source: Author's processing according to the results of empirical research

In order to examine the extent to which the respondents who would experience age discrimination in the future would be willing to respond and seek protection of their rights in court, they were asked the following question:

"In case you personally experience age discrimination, would you turn to the court to protect your rights if other options (addressing the employer, addressing the union commissioner, the ombudsman) were exhausted?" and they were offered the following answers:
a) I would certainly go to court
b) I would probably go to court
c) I would probably not go to court
d) I would certainly not go to court

In order to protect their rights, in case other possibilities (addressing the employer, addressing the trade union commissioner, ombudsman) would be exhausted, $31.39 \%$ of the respondents would probably go to court, and only $13.53 \%$ of respondents would certainly go to court if they were in such a situation. 
Graph 3 Potential recourse to court after exposure to age discrimination

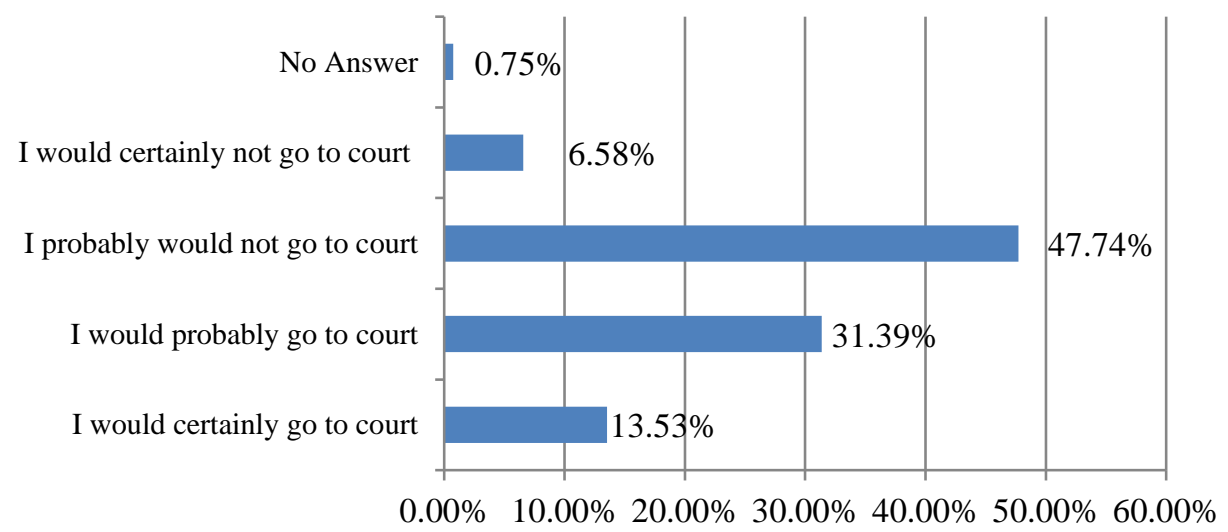

Source: Author's processing according to the results of empirical research

With regard to going to court, a statistically significant difference was found between the respondents employed based on a permanent full-time employment contract, those employed on a fixed-term basis and those employed on a parttime basis. As can be seen from the table, respondents who work on permanent full-time basis would more often certainly go to court in case of exposure to age discrimination than members of the other two groups would.

Table 7 - Potential recourse to court after exposure to age discrimination - by type of employment contract

\begin{tabular}{|l|l|l|l|l|l|}
\hline & $\begin{array}{l}\text { I would } \\
\text { certainly } \\
\text { go to court }\end{array}$ & $\begin{array}{l}\text { I would } \\
\text { probably go } \\
\text { to court }\end{array}$ & $\begin{array}{l}\text { I probably } \\
\text { would not go } \\
\text { to court }\end{array}$ & $\begin{array}{l}\text { I would } \\
\text { certainly } \\
\text { not go } \\
\text { court }\end{array}$ & Total \\
\hline $\begin{array}{l}\text { Permanent } \\
\text { full-time }\end{array}$ & 61 & 110 & 155 & 20 & 346 \\
\hline $\begin{array}{l}\text { Fixed-term } \\
\text { full-time }\end{array}$ & $17,63 \%$ & $31,79 \%$ & $44,80 \%$ & $5,78 \%$ & $100,00 \%$ \\
\hline Part-time & $6,63 \%$ & $29,52 \%$ & $55,42 \%$ & $8,43 \%$ & 166 \\
\hline Total & $0,00 \%$ & $46,67 \%$ & $46,67 \%$ & $6,67 \%$ & $100,00 \%$ \\
\hline
\end{tabular}

$\chi^{2}=17,19 ; \mathrm{p}=0,00 ;$ Cramer's $\mathrm{V}=0,13$

Source: Author's processing according to the results of empirical research 
In order to determine the reasons why the respondents would not go to court, they were asked the following question:

"If you certainly or probably would not go to court, state the reasons why you would not do so"
a) lengthy proceedings
Yes No
b) distrust of the court
Yes No
c) high costs of the proceedings Yes No
d) any other reason (state which: )

The results of the research showed that distrust of the court and the length of the proceedings are the most common reasons for not going to court, which can be seen from the following chart.

Graph 4 Reasons for not going to court in case of exposure to age discrimination (more than one answer possible)

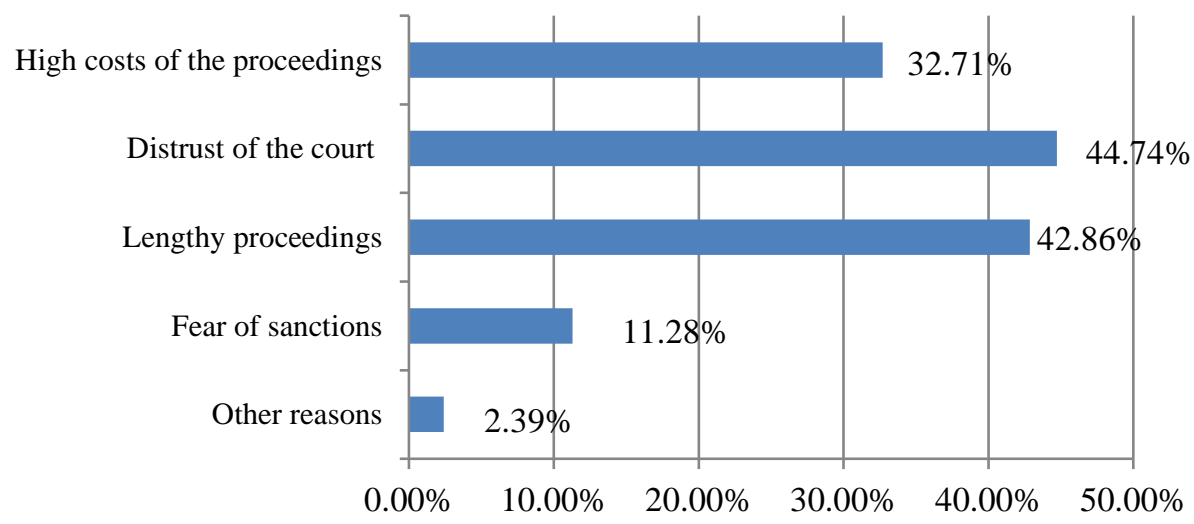

Source: Author's processing according to the results of empirical research

In this case, too, statistically significant differences were found between the respondents employed on the basis of a permanent full-time employment contract and the other two groups. This group of employees rarely cited the length of the proceedings and the high costs of the proceedings as the reason for not going to court, which is evident from the tables that follow. 
Table 8 - Failure to go to court due to the length of the proceedings - regarding the type of employment contract

\begin{tabular}{|l|l|l|l|l|}
\hline \multicolumn{2}{|c|}{ Yes } & No & Total \\
\hline $\begin{array}{l}\text { Permanent } \\
\text { time }\end{array}$ & full- & 135 & 212 & 347 \\
\hline $\begin{array}{l}\text { Fixed-term } \\
\text { time }\end{array}$ & full- & $85,90 \%$ & $61,10 \%$ & $100,00 \%$ \\
\hline Part-time & $51,20 \%$ & 81 & 166 \\
\hline Total & 8 & $48,80 \%$ & $100,00 \%$ \\
\hline & $53,33 \%$ & 7 & 15 \\
\hline
\end{tabular}

$\chi^{2}=7,58 ; \mathrm{p}=0,02 ;$ Cramer's $\mathrm{V}=0,12$

Source: Author's processing according to the results of empirical research

Table 9 - Failure to go to court due to high costs of proceedings - regarding the type of employment contract

\begin{tabular}{|c|c|c|c|}
\hline & Yes & No & Total \\
\hline $\begin{array}{l}\text { Permanent full- } \\
\text { time }\end{array}$ & $\begin{array}{l}98 \\
28,24 \%\end{array}$ & $\begin{array}{l}249 \\
71,76 \%\end{array}$ & $\begin{array}{l}347 \\
100,00 \%\end{array}$ \\
\hline $\begin{array}{l}\text { Fixed-term full- } \\
\text { time }\end{array}$ & $\begin{array}{l}69 \\
41,57 \%\end{array}$ & $\begin{array}{l}97 \\
58,43 \%\end{array}$ & $\begin{array}{l}166 \\
100,00 \%\end{array}$ \\
\hline Part-time & $\begin{array}{l}7 \\
46,67 \%\end{array}$ & $\begin{array}{l}8 \\
53,33 \%\end{array}$ & $\begin{array}{l}15 \\
100,00 \%\end{array}$ \\
\hline Total & $\begin{array}{l}174 \\
32,95 \%\end{array}$ & $\begin{array}{l}354 \\
67,05 \%\end{array}$ & $\begin{array}{l}528 \\
100,00 \%\end{array}$ \\
\hline
\end{tabular}

$\chi^{2}=10,34 ; p=0,01 ;$ Cramer's $V=0,14$

Source: Author's processing according to the results of empirical research 
Knowledge of anti-discrimination legislation and readness to seek...

\section{Discussion- application of the results of empirical research in order to answer the questions presented in the paper}

In addition to the questionnaire, primarily to check the existence of age discrimination in the perception and experience of the respondents, the author also wanted to further check whether and to what extent respondents are familiar with the Croatian anti-discrimination legislation or whether they are aware of the Law on Elimination of Discrimination and its contents. The results of the research showed great ignorance of the Law, more precisely only $21.43 \%$ of respondents know that there is the Law on Elimination of Discrimination in the Republic of Croatia. It is astonishing that more than $76 \%$ of respondents are not familiar with the contents of the Law and therefore neither with their rights (Chart 1). Knowing the law and legal possibilities is a prerequisite for combating any form of discrimination. This data is even more astonishing if we take into account the fact that as many as $89.29 \%$ of respondents with a university degree participated in the research, which may indicate a certain lack of interest of respondents in this issue.

The case law regarding age discrimination in the Republic of Croatia is more than modest. Therefore, this research also sought to check how many respondents who experienced age discrimination responded in any way and how many of them would go to court to protect their rights, if they were exposed to such illicit treatment in the future due to age. The results of the survey showed that out of the respondents who were exposed to age discrimination, only $15.43 \%$ responded in any way, while a surprisingly high percentage, as many as $84.57 \%$ of respondents would not react at all.

The causes of insufficient reporting of discrimination are certainly insufficient information of respondents regarding both anti-discrimination legislation and its content, fear of stigmatization, but also inefficient and expensive system of judicial protection. A special problem in the Republic of Croatia is the widespread attitude of citizens about discrimination as a "normal" phenomenon for which in most cases there is no adequate judgment of the judicial bodies, and which ultimately has a disincentive effect on its reporting.

In the context of the possibility to turn to the court for protection of their rights in case of exposure to age discrimination in the future and after the exhaustion of all other possibilities, only $13.53 \%$ of respondents would certainly go to court. On the other hand, more than $50 \%$ of respondents would probably or certainly not go to court in such a case. It is important to point out that the results of the research showed that, in this respect, there is a statistically significant difference between respondents employed under permanent fulltime employment contracts, those employed under fixed-term full-time employment contracts and those employed part-time in such a way that fulltime respondents would go to court more often if they were exposed to age discrimination. Such results may indicate that respondents who are employed for an indefinite period of time fear less for their job and therefore they are more 
inclined to turn to the competent institutions, in this case, the courts, to protect their rights.

The results of the empirical research showed that as many as $44.74 \%$ of respondents would not go to court because they do not trust it, while $42.86 \%$ of them would not go to court due to the length of the proceedings. This situation necessarily requires changes, changes aimed at restoring Croatian citizens' faith in the courts, the belief that the courts judge exclusively "by law" and that judges are objective, independent experts who protect their rights. On the other hand, a significant number of respondents, $11.28 \%$, would not go to court for fear of sanctions. These data indicate the need to continuously take measures aimed at providing effective protection to victims of discrimination in order to be as ready as possible to turn to institutions for help, with emphasis on consistent law enforcement because the regulation achieves its purpose only if implemented and it requires both social and political will.

\section{Conclusion}

The conducted empirical research has given rise to several problems: the reluctance of respondents, victims of age discrimination to report cases of discriminatory treatment, the reluctance of respondents, potential victims of age discrimination to go to court to protect their rights as a last resort, if all other options such as turning to the employer; the trade union or the trade union commissioner or the ombudsman were exhausted and the low level of awareness of the existence of the Law on Elimination of Discrimination and its content. This situation could be a good reason for conducting systematic training of employees on anti-discrimination regulations and the opportunities available to current and future victims of discrimination. The implementation of such training through lectures, seminars and workshops should be established as an obligation of the employer, while for the unemployed such an obligation should be taken over by the Croatian Employment Service or its regional services. This should result in the raising of the level of awareness of citizens about discriminatory treatment as illicit treatment, encouraging them to oppose such treatment. This research also showed that citizens in the Republic of Croatia do not trust the courts and that Croatian court proceedings are known for longevity. As many as $44.74 \%$ of respondents would not go to court because they do not trust the legal system, while $42.86 \%$ of them would not go to court due to the length of the proceedings. These data show that taking effective measures is a necessity.

The question is how to restore citizens' faith in the Croatian judiciary. The problem is complex, so the measures to solve it must also be such. One of the steps that should yield positive results is certainly ensuring the independence of judges and taking measures that are more effective in the fight against corruption. A special problem of Croatian courts is the different understanding 
and interpretation of regulations, which results in endangering the legal security of citizens and their equality before the law. Therefore, this problem should be approached extremely seriously. Thus, with regard to adjudication of lawsuits for discriminatory treatment, inconsistent treatment was found in cases of identical facts, failure to apply the institutes provided for by anti-discrimination legislation and failure to apply the practice of European courts. It should be emphasized that the application of the practice of European courts is one of the obligations of Croatian courts arising from the founding treaties. This situation in the conduct of Croatian courts requires changes. Changes aimed primarily at educating judges, which could ultimately have positive effects on the protection of subjective civil rights.

Therefore, there is a need for continuous professional development of judges in terms of anti-discrimination legislation, European law and its application. In this regard, it should be noted that the Report of the Judicial Academy for 2016 shows that in terms of participation of judges in professional development activities, as many as $48 \%$ of participants participate only once, $25 \%$ of participants participate twice, and only $1 \%$ of participants in these activities participate eight and nine times, respectively. Furthermore, it is necessary to increase the number of workshops on anti-discrimination legislation and the application of EU law, since in 2016 only one workshop was held on this topic. What is particularly worrying, and what is also evident from the aforementioned Report, is the fact that the number of participants in seminars on discrimination is extremely small. To illustrate this, the seminar on equality between men and women in European law was attended by only five participants, while the seminar on the Charter of Fundamental Rights of the European Union in practice was attended by only two participants. The high level of disinterest of Croatian judges in this issue is worrying, which is why it is necessary to work on encouraging their participation in these forms of training, prescribing, for example, participation in such activities as one of the conditions for their advancement. Therefore, changes in the judicial system are necessary, and if the previously proposed measures result in regaining faith in the Croatian judiciary by at least one Croatian citizen, it will be, albeit small, a step forward. 


\section{References}

Bjelić, D. (2018). Dobna diskriminacija u radnim odnosima [Age discrimination in labour relations], Veleučilište u Požegi, Požega

Butler, R.N. (1969). Age-Ism: Another Form of Bigotry, The Gerontologist, Oxford University Press, New York

Civil Procedure Law (Official Gazette No 53/91, 91/92, 58/93, 112/99, 88/01, 117/03, 88/05, 02/07, 84/08, 123/08, 57/11, 148/11, 25/13, 89/14, 70/19)

Consumer Protection Act (Official Gazette No 41/14, 110/15,14/19)

Cuddy, A. J. C., Fiske, S.T. (2002). Doddering but Dear: Process, Content, and Function in Stereotyping of Older Persons. In :Nelson, T.D. (Ed.), Ageism: Stereotyping and Prejudice against Older Persons, MIT Press, Cambridge, Massachusetts

De Prins, D., Sottiaux, S., Vrienlink, J. (2005.) Handboek diskriminatierecht, Kluwer Law International

Dika, M. (2003). Udružna tužba kao instrument apstraktne zaštite potrošača [The Class action as an instrument of abstract consumer protection], Hrvatska pravna revija, No 10, 37- 43.

Frntić, D., Maričić, D.(2006). Diskriminacija i zlostavljanje unutar radnih odnosa [Discrimination and abuse within labor relations], Centar trajnog savjetovanja u poslovanju, Zagreb

Iversen, T. N., Larsen, L., Solem,P. E. (2009). A conceptual analysis of Ageism, Nordic Psychology, Vol. 61(3), 4-22

Johnson, J., Bytheway, B. (1993). Ageism: concept and definition. In: Johnson, J., Slater, R. (Eds.), Ageing and later life, The Open University: Sage Publications

Law on Elimination of Discrimination (Official Gazette No 85/08, 112/12)

Levy, B.R., Banaji, M.R. (2002). Implicit Ageism. In: Nelson,T.D. (Ed.), Ageism: Stereotyping and Prejudice against Older Persons, Cambridge, Massachusetts: MIT Press, 49-75

List, J. (2004). The Nature and Extent of Discrimination in the Marketplace:

Evidence from the Field, Quarterly Journal of Economics, Vol. 119, No 1, 4989

Macnicol, J.(2006). Age Discrimination, An Historical and Contemporary Analysis, Cambridge University Press, New York

McGowan, T.G.(1996). Ageism and Discrimination. In :Marshall,V.W. et.al. (Eds.), Encyclopedia of Gerontology:Age, Aging, and the Aged. Academic Press, San Diego

Miličić, V. (2008). Opća teorija prava i države [General Theory of Law and the State], Zagreb

O'Cinneide, C. (2010). Age Discrimination and the European Court of Justice: EU Equality Law Comes on Age, available at: www.eracomm.eu/oldoku/Adiskri/08_Age/

2010_09_OCinneide\%20EN,\%20predsude\%20dob\%20diskr\%20ESP. pdf, accessed on 02.12.2021 
Pavlović, M. (2001). Vrste tužbi i njihove pravne karakteristike [Types of lawsuits and their legal characteristics], Hrvatska pravna revija, No $7,105-112$

Pavlović, Š. (2009). Komentar Zakona o suzbijanju diskriminacije [Commentary on the Law on Elimination of Discrimination], Organizator, Zagreb

Pearson, M. (1996). Experience, skill and competitiveness: The impication of an ageing population for the workplace, European Foundation for the Improvement of Living and Working Conditions, Dublin

Report of the Ombudsman of the Republic of Croatia for 2020, available at: https://www.ombudsman.hr/hr/download/izvjesce-puckepravobraniteljice-za-2020-

godinu/?wpdmdl=10845\&refresh=61ad5048b21a91638748232, accessed on 3.12.2021

Report of the Ombudsman of the Republic of Croatia for 2019, available at: https://www.ombudsman.hr/hr/download/izvjesce-puckepravobraniteljice-za-2019godinu/?wpdmdl=7580\&refresh=61ad50fe1747c1638748414, accessed on 3.12.2021

Rodin, S. (2003). Jednakost muškaraca i žena, Pravo i politika u EU $i$ RH [Equality between men and women, Law and Politics in the EU and the Republic of Croatia], Institut za međunarodne odnose, Zagreb

Sargeant, M. (2011). Age Discrimination, Ageism in Employment and Service Provision, Middlesex University, UK

Snape,E., Redman, T.(2003). Too old or too young? The impact of perceived age discrimination, Human Resource Management Journal, Vol 13, No $1,78-89$

Triva, S., Dika, M. (2004). Građansko parnično procesno pravo [Civil Procedure Law], Narodne novine, Zagreb

Tryfonidou, A. (2009). Reverse Discrimination in EC Law, Kluwer Law International, Netherlands,

Uzelac, A. (2010). Postupak pred sudom [Court proceedings] in: Šimonović, Einwalter, T. (ed.), Vodič uz Zakon o suzbijanju diskriminacije [Guide to the Law on Elimination of Discrimination], Ured za ljudska prava Vlade Republike Hrvatske, Zagreb

Westen, P. (1982). The Empty Idea of Equality, Harvard Law Review, 95 (3), $537-596$

\section{Judgments of the Court of Justice of the EU and the European Court of Human Rights}

Court of Justice of the EU, Case C-144/04 Werner Mangold v Rudiger Helm (2005)

Court of Justice of the EU, Case C-227/04 Lindorfer v Council of the European Union (2007) 
Court of Justice of the EU, Case C-17/05 B.F. Cadman v Health and Safety Executive (2006)

Court of Justice of the EU, Case C-411/05 Felix Palacios de la Villa v Cortefiel Servicios (2007)

Court of Justice of the EU, Case C-427/06 Birgit Bartsch v Bosch und Siemens Hausgerate Altersfursorge Gmb (2008)

Court of Justice of the EU, Case C-388/07 Age Concern England v Secretary of State for Business, Enterprise and Regulatory Reform (2009)

Court of Justice of the EU, Case C-555/07 Seda Kücükdeveci v Swedex GmbH (2010)

Court of Justice of the EU, Case C-88/08 Hütter v Technische Univerzitat Graz (2009)

Court of Justice of the EU, Case C-229/08 Colin Wolf v Stadt Frankfurt am Main (2010)

Court of Justice of the EU, Case C-341/08 Dr Dominica Peterson v Berufungsausschuss fur Zahnaerte fur den Bezirk Westfalen-Lippe (2010)

Court of Justice of the EU, Case C-45/09 Gisela Risenbladt v Oellerking Gebaeudereinigungsgesselschaft (2010)

Court of Justice of the EU, Case C-246/09 Susanne Bulicke v Deutsche Büro Service Gmb (2010)

Court of Justice of the EU, Case C-20/13 Daniel Unland v Land Berlin (2015)

Court of Justice of the EU, Case C-159/15 Franz Lesar v Beim Vorstand der Telekom Austria AG (2016)

Court of Justice of the EU, Case C-258/15 Gorka Salaberria Sorondo v Academia Vasca de Policia y Emergencias (2016)

European Court of Human Rights, Abdulaziz, Cabales, Balkandali v UK, App. No 9214/80, 9473/81 and 9474/81 (1985) 